\title{
A espiritualidade em tempos de pandemia
}

Orientadora: Profa. Francilaide de Queiroz Ronsi

Pesquisadora: Gislane Reis Ribeiro Toledo

Fonte: $\mathrm{CNPq}$

\section{Introdução}

O mundo já viveu muitas outras pandemias, mas a profunda crise que vivemos hoje causada pela Covid-19, tanto expõe a desigualdade socioeconômica, marcada pela escolha de uma economia que desconsidera as necessidades humanas e o cuidado com o meio ambiente, como também deixa exposta a fragilidade das relações humanas e da vida espiritual. Nesse sentido, a nossa pesquisa deseja saber como a prática de uma espiritualidade e a solidariedade se fizeram presentes na vida das pessoas durante o período de isolamento social. Dentre muitos autores, contaremos para a nossa reflexão, com a contribuição do Papa Francisco, que nos alerta para não pensarmos só nos nossos interesses, mas aproveitemos esta prova como uma oportunidade para preparar o amanhã sem descartar ninguém.

\section{Objetivos}

O nosso objetivo foi identificar a espiritualidade no seu aspecto antropológico e religioso que surge da experiência de distanciamento social exigido pela pandemia. Para isso, utilizamos o método de entrevista qualitativa e padronizada para identificar e entender quais serão as consequências desse distanciamento social para a espiritualidade cristã. 